\title{
The Great Time, the Three Societies in the Globalization and the Three Souls of a Leftist Today
}

\author{
Endre Kiss
}

Department of Philosophy, the University Eötvös, Budapest 1088, Múzeum körút 8, Hungary

\begin{abstract}
The first society would be the society of the good will. Already several times discussed, for which the value-oriented life of this year can no longer become an open problem. We define the second society provisionally as the one, which is fundamentally not constituted by the above described good will. In the following, we will try to identify it in this abstract description as the society of the "majority". We see the third society in that political class or elite, which power has been built in the year 1989 and thus became the concretization of that establishment, with which the "first" society identified itself so totally. This tripartition of the real existing Left might also explain, why its political articulation is so fragmented. A Leftist should have today three souls: one of the winners (the elite, as a member of our third class), one of the losers (as a member of our second class) and one of the man of good will (as a member of our first class), who very enjoyed in its total identification with the own system). And authors have drawn some meaningful conclusions.
\end{abstract}

Key words: Political hermeneutics, splitting of society, cleavage, globalization, global society, identification, thrust, manipulation, society of good will, media possession.

\section{On the Great Time}

The conception of this work requires some explanation. In it, we try to unite with each other two different ways of approach.

One of the approaches is theoretical-scientific, implemented throughout decades of researches of the author on the theoretical interpretation of the globalization. This first approach is, not only in one single respect, not quite disciplinar or paradigmatic, it is moving in the new waters of a globalization research, that appeared with the exigence of a theory building [1].

The other approach (and simultaneously practicized) is however essayistic, and excludes also no personal notes. This approach is, as it seems to us, in 2015, 2016 and 2017, a necessity quite prescribed by the history, which for these years brought in the processes of the globalization a range of new facts and new facts' configurations, which arouse at least intellectually

Corresponding author: Endre Kiss, Ph.D., D. Sc. Professor, ELTE-OR-ZSE, research fields: philosophy and globalization. also personal reactions and reflections. Afterwards, we are hardly mistaken in the self-reflection, because we think, that these personal reflections are not really particular or subjective, but are articulating in front of the horizon of the long theoretical work.

The most outstanding association of the beginning should come from Karl Kraus, from this Vienna's original thinker of the pre-war period.

Kraus came often to the idea: "We are living in great epochs!"

Kraus' "great epochs" are evidently anything but just "great". The simple reversal of the language is however not yet the solution itself.

\section{Understanding What?}

The situation of the today's world, in other words the state of the present globalization shows two extremely rare and complex difficulties, that are also beginning to have an impact in many other domains.

One of them is the problem of the understanding, a kind of hermeneutics then, i.e. the problem that the diverse individuals, the normal actors, the citizens of 
the democracy (so strongly and quickly they can modify also their conditions of existence) are hardly or not at all in the situation to understand the processes deploying, in the original sense of the word, in front of them [2].

To understand the present, and as said, the "everyday" processes in the general sense of the word, the usual actors of our time should realize an age, that consists in an infinity of many small facets, is scattered all over the globe, spreads in many languages and is reworked, because of the enormous quantity of information, is not at all comprehensible, that they independently understand moreover conceptualized in the context of a diversity of old and new, known and still unknown ideologies [3].

But it is not all.

One can quite rightly beforehand indicate (in the face of the vast hermeneutic necessities, "anticipate"), that this concrete present, this concrete state of the globalization is existing in an extremely complex way, moreover historically unprecedentedly, numerous facts are hidden behind the superficiality (partly unintentionally, because of the enormous extent of the traffic of informations, partly willingly, because of particular interests, partly however also because of the legal generosity of the largely established personal rights).

The concrete present is reproduced by numerous moments, facts and other complex real processes, that go to meet the principles of the last thirty years. In this age (in order, with a certain simplification, to make clear this thesis, we would establish the beginning of this world-historical period in 1989), it was possible for the citizen of the world history to identify himself also on a fairly long-term basis with the leading line of the history [4]. After long and crual historical periods, this happened in those where this citizen of the world history had to resist to the mainstream, where he could realize constantly his fundamental values with the biggest sacrifices and-it would not be moral to keep silent on the fact, that he had there often to struggle for his pure survival.

After 1989, the possibility of the hope opened then in front of the citizen of the world. It was the position of the good will, which can be easily responsible intellectually and morally, This identity invests a growing sensitivity and confidence in the once-found right way, on which one should only go further. One can only answer on the fact that the nature of the power had also changed by means of a particular political-scientific thought process.

The other, second of the specific difficulties, mentioned at the beginning, of the present situation of the world (of the "state of the globalization") is also new, unprecendented and very difficult to categorize. Up to the year 2010, this specific dichotomy of the political system in every individual society has certainly become reality, we should also debate of the diverse differences of the various "splittings". The political reality is expressed in the "splitting".

\section{The Unexpected Golem of the Splitting in Recent Democracies}

The "splitting" is a fundamental fact in the political system of every recent democratical state. This cleavage, the "two-party system", the division of the political classes as well as also of the political opinions camps in two groups opposing to each other roses like a golem and determined the political agenda.

In its reality, it is also symbolic, with which clarity the phenomenon of the splitting envisaged here has dominated the domain during the presidential elections in the USA in 2016. It is sufficient for us to inform here on the tangible reality of this manifest cleavage, and indeed in that context, how obviously this global and prevailing reality could make fail the understanding of such incommensurable and unprecedented phenomena, such as the globalization or the climate change.

Not only the phenomena, but also their theoretical characters are then quite new, since we have now to 
do with the context, of how a political reality ("the splitting") can come to an epistemological dimension. This Splitting" prevents knowledge, because its power, the power of the effective domination of the political reproduction, can considerably shape the process, how the real conditions of the globalization are becoming visible behind the structures of the political splitting.

The cognitive catastrophe for the global citizen originates from the state of the splitting through the fact, that he was forced previously to already choose one side or the other. Even in this choice, intellectual and epistemological considerations are perfectly eliminated, for it would be truly astonishing, if we say, that the system of the positions of one side of the political splitting would stand intellectually and epistemologically at the height of the human civilization, that this position would simply be identical to the right consciousness in the epistemologic sense.

This choice between one pole or the other of the splitting has quite diabolic consequences. By choosing one pole, it is holistically evicted and excluded by the other. If one denies this choice, one then condemns itself thereby to the complete political solitude, one is excluded from the politics, and is accepted in the circle of the information circulation of no party.

Thus, a hitherto unprecedented cleavage occurs (said with the inevitable theoretical generalization) in the global society. About the global character of the "splitting", or about its relations with the globalization, we have not yet formulated any statement, it is about the fact, that the processus of understanding and interpretation of the globalization in the cognitive universe of the global citizen is following its course in a political milieu, which is penetrated by this cleavage.

This colossal Gran Canyon is then also worth being in itself considerably chosen as object of particular investigations.

This huge break line is undoubtedly a leading train of an "ontology" of the globalization. It is precisely in this unfixed position between global ontology and political break line, that the phenomenon of the "splitting" signals, in its real extent, the arrival of a new global structure, which is no longer determined by the dichotomy of the world or by the crucial and provocative existence of the communism.

The free struggling splitting of the real social groups (or also parties) also leads to as well unprecedented phenomena in the fact, that this will represent with the same impulse, in numerous determining and not rarely immediately global questions, positions standing extremely strongly in opposition to each other.

In such huge questions like the climate change corresponds or not, one must create jobs in the economical politics or must have recourse to "outside sources", the migrants are enrichment of the spiritual substance of a nation or they are living biocatastrophe, the oil still works or not, the drog means the death or the revolution of the school system, the geopolitics is legitimate or politically incorrect, the state-nations are existing entities or self-fulfilling bodies stands the positions extremely strongly in opposition to each other.

It means then for the intellectual (communicative, ideological, value-orienting) world of the globalization, that there are no longer any theoretical positions opposing to each other (that can be integrated without any difficulty in the global culture of the discussion), but two imperturbable centers which, from the beginning, have their position about all pertinent problems and consider the acceptation of this position as the condition of the appartenance to their political pole.

Thus, we arrived to the astonishing point of contact of both extremely rare and complex difficulties, that stand in the way of the global world citizen in the way of the intellectual and cognitive adaptation in a breathtaking manner.

It is in fact a situation, that is not far at all from Karl Kraus' characterization, "we live in great times". 
On the one side, we stated: to understand the "everyday" processes in the general sense of the word, the usual actors of our time should realize an age, that consists in an infinity of many small facets, becomes scattered throughout the whole globe, simultaneously runs and is constructed on many languages, is not comprehensible because of the enormous extent of informations, moreover is conceptualized in the context of a variety of old and new, known and still unknown ideologies.

On the other side, we stated: it means for the intellectual (communicative, ideological, value-orienting) world of the globalization, that there are no longer any theoretical positions opposing to each other, but two imperturbable centers, which consider the acceptation of this position as the condition of the appartenance to their political pole.

It is clear, that the global citizen is experiencing a real test. He is standing in front of hardly solvable dilemmas, while the splitting makes it considerably impossible to thematize or to deal with the dilemmas.

Freedom and repression are again appearing in the form of new phenomena.

While in the real socialism (to take only this example), thinking was liberated on all sides, it was only alluded to few "taboos", which might only be judged in a single way.

In the neoliberal globalization after 1989, the dichotomy "freedom-repression" is appearing in a new way. On the one side, the thinking is also in itself considerably liberated, while the criteria and dimensions of the real globalization are making almost impossible to construct a specific hermeneutics of the globalization. Nothing is publicly made a taboo subject (the attempts of the "politically correct" are going in this direction, do however not reach the degree of the theoretical relevance). The considerably free thinking however comes in the purely "external", one hundred per cent "political" situation, if we want, the "political constraint" to accept the positions of one or another pole or to be politically and socially downgraded (in a "free" society). It is incredibly pertinent, that the "political constraint" of the global citizen, to abandon its freedom in favor of one or another pole, is distinguishing itself crucially from the "structural constraint" or "system constraint" of the real socialism, which restricted the freedom of his thought and formation of opinion through and rules made a taboo subject.

If Karl Kraus would have experienced this real test in its true concrete form, he would probably also have been quickly recognized publicly in our days with the thesis "about the great times".

While we want soon to describe the global society also as a "society of the good will", it is already so much clear, that "the good will", which is mentioned here and not yet realized, a reaction also on the "splitting" is worth of interest. If also other relations are linking this society with the represented real test ("infinite complexity-merciless splitting"), we can answer only at the end of this thought process.

After 1989, which is, also as the date of beginning of the globalization, it was given to the value-oriented and exigent men, to identify themselves with the democratic system and in it also, intensively and all-round, with their own democratic establishment.

\section{Unprecetended Good World}

This honest and intensive identification with the own system was certainly the product of the message of the year 1989, a certain "end of the history", that appeared in a macro-extent undoubtedly as a model, that was better as the previous one.

From a perspective of the increasing temporal distance, this phenomenon of the total identification with the own system reminds, with the best conscience, of phenomena of the sixties. It is here not about the peak points of the movement of the new Left, rather about the much slower change of values, in which many wanted to live value-oriented, have overcome positions of the new Left of that time, without wanting to have named themselves under the 
name of Left. This belongs also to the history of the invisible transition from the new Left to the neoliberalism, in other terms, from 1968 up to 1989 , on which the author of these lines has also written a lot of studies, without having really thought at that time how much the thread of this transition was pertinent. Another important heuristic point in a possible reconstruction is that mysterious modification, of how finally similar contents are transformed, on the political pallet, from "left" toward "right".

It is a fact, that this process of 1989 of the self-identification with the own system in the soul of this new group of the citizens, wanting to live consciously value-orienting, was going on as it was the case after 1968. The movement of the huge world-historical pendulum undoubtedly began already in the midst of the seventies (i.e. still far before 1989). This shows also the sense of the vacuum let by itself by the new Left (although we can still hardly comprehend the diverse components of this process).

Such a profound self-identification with the own society is for the own political representatives a "social fact" in Emile Durkheim's sense which, as determining fact, must have and has also effectively a range of consequences.

One of these consequences is, that it can be an instrument suggesting to the power or to the establishment of such a society to manipulate this profound self-identification, this obvious confidence, to build on this attitude such as on a solid pillar in the political universe.

The possibility of the manipulation is in principle spontaneous here, it is not necessarily provoked by situations of constraint of the concerned establishments. It is in principle also from the beginning so, that this intensity of the identification can hand over spontaneously the people concerned at any time to the manipulations of the establishments.

This new master-servant relationship spontaneously emerges then immediately after the crystallization of the original basic situation. The best social order is here, without any reason to identify itself with joy, the social fact becomes reality.

1989 brought with its credible message, a revolution of the good will.

The big splitting integrated also this phenomenon of the new society of the good will.

If we come once to a manipulation of the society of the good will, which remained with the values of the year 1989, then we have again to do with a quite new phenomenon, even also with a new phenomenon of a new nature.

\section{Borderless Identification by Suspension of the Sense for Reality}

The novelty of this manipulation is, that this time it is not aimed at the deprived, the wretched, the poor or social classes, that should be appeased or diverted in the articulation of their real rights and disadvantages. This time manipulats erxactly the same classes, which were and are identifying themselves with the establishment and therefore are also satisfied with the state of the world and the globalization.

Between the ideally accepted total identification (with the new world) and the manipulation (not yet quite totally realized), we can consider the turning point of the historical credibility of the new establishment of the year 2004 (George W. Bush's Iraq war) or of the year 2007-2008 (world financial crisis). After such a turn point, the necessity of the manipulation accordingly increased also strongly [5].

The new freedom of the year 1989 meant an all-round freedom of the criticism. In the states of the late communism, it is well-obvious, that it was not different in the western states, over which the enthusiasm has also spread.

One of the realizations of the possibility of manipulation (of the new and specific master-servant relation), contained in the situation of the total self-identification, was that partly certain also spontaneous change, that the all-round criticism did not only remain impassible, but has become the 
symbol of the new world democracy. At the same time, we see that the essential criticism of the new political attitude is hardly no longer existing.

We however do not forget, that the structurally, already for long, integrated Marxist criticism, has been at that time practically disqualified. We also not forget, that the value-oriented attitude of the year 1989 was no longer considerably considering its own time as problematic, the positive, quite apologetic train was belonging to its nature.

Moreover, the new culture of the all-round criticism has also not been supplemented by ever new rules of the correct behavior, by ever new rules of the correct speech, although precisely the society of the good will also spontaneously and independently think that, in 1989, a qualitative leap in the world history occured.

If one follows this line, one is soon confronted with well-known phenomena of the last decades.

The result is striking, in the criticism, already became of second nature of men, the share of "empiricism" has always declined, although that of the criticism grew just as straightforwardly. A growing criticism with a shrinking share of empiricism is however only possible, if the proportion of manipulation also increases in the overall process [6].

After the East-European real socialism and the West-European conformism (one must also add to this already the "new" leftist conformism), we may by the way not be at all surprised, that the stabilization of the criticism as social activity produced a profound enthusiasm, which also led to the self-identification with the own reality, although this establishment might also much recognize, that one can lean largely and perspectively upon this attitude.

This is the more profound reason of the already once mentioned proximity, if not encountered of the culture of the criticism and of the deconstruction issuing from the post-modernism. On this line, manipulation is deconstruction and deconstruction manipulation [7].

Starting from the birth of a striking attitude which, on the basis of the interpretation of the year 1989, identified itself largely with the political and social (and global) institution of the new time, we draw up a hypothesis about three "societies", that emerged from these sources. The designed "three societies" form the new ether for the interpretation of the global world society existing in the history.

They provide a new possibility of description of the global reality, in a certain analogy to the natural descriptions of our days, we look to the fact that the one description does not make superficial or deny the others, and every description refers to its truth content from the definitions of its perspectivistic peculiarity. We take for real the existence of these three global societies, even if we do not deal with the sociological description for instance on a meso-level.

\section{On Multiface Game of Three New Classes}

The first society would be the society of the good will. Already several times discussed, for which the value-oriented life of this year can no longer become an open problem. We define the second society provisionally as the one, which is fundamentally not constituted by the above described good will. In the following, we will try to identify it in this abstract description as the society of the "majority". We see the third society in that political class or elite, which power has been built in the year 1989 and thus became the concretization of that establishment, with which the "first" society identified itself so totally.

The "third" society is the object of the self-identification of the "first". The "first" is the product of the year 1989. The "second" society lived after 1989 rather long in the shade, its emancipation began only after the first shakes of the new world order. It is therefore a great question of the history: what does the historical fate of the "second" society become? Which is on the way to demonstrate the "majority"? The relations of the three societies are produced as a reaction to the turn of 1989, the End of Communism, the victory of Neliberalism and the new 
Hegemony of Left-Liberalism.

They are however living in the deeply indebted state.

The "third" society suggests often to the "first" society, that the indebted state is not the relevant event or the relevant fact, rather that the dismantling of the state is a progress, that is precisely going to meet the individualizing and liberal velleities of the "first" society. The "second" society is however without any doubt the clear loser in the condition humaine of the indebted state.

For the establishment of the period after 1989, nothing might have been in abstracto more profitable than the weakness of the national sphere, which poured out of the indebtedness. It can implement private power plants and private universities, it can buy media or media empires, and it is also largely free from any further state control.

In the co-ordinated interplay of the "first" and the "third" societies, the "second" society appears constantly and really without the details of a concrete situation, as potential "enemy". It has to be seen so, because the "third" society can not at all imagine that this society will bear its deprivation, impoverishment and social humiliation without any resistance. For precisely the "third" society knows most exactly which profits of any kind it has already drawn from this change, and it remains nothing but the "first" class to believe in the interpretation models of the "third" society about the nature of the "second" society.

The three "societies" can be excellently characterized and classified on the axis of the media poverty and media wealth. The "third" society owns the mediality in every sense of the word. It uses the medias to preserve with it (the "third" society) the "first" society in its enthusiasm and complete self-identification. The "second" society is not considered as a target group, has itself no media, appears in the media for instance as a "victim" or as a "potential danger".
The status of distribution of the media ownership (and its ever-talented use) precisely underlines the importance of Assange and Snowden, this situation creates precisely the right context for their publications. Philosophically expressed, in a culture of the criticism, where the empiricism is missed out, the billions of information makes public should strive for a balance. This revolution of the empiricism shook the credibility of the "third" society. The "first" society can free itself from the enchantment of the "third" society. The "second" society can breathe deeply, but still has much to suffer until it succeeds in articulating itself positively.

The "three" societies are not necessarily developping in their parallelism in the political direction in the sense, that they once appear in a representative state as three vast parties. It seems to us that they are evolving in the direction of three great thought communities, for instance toward three "religions" in a not yet exactly identified sense of the word.

Fully roughly outlined: the "first" society goes in the sense of a new and of a new type christianity ("Man is good"), the "second" society is wrapping around a new "religion", while it wants to escape from the chaos of the new mass culture and of the old resentment. Today, we already know the "religion" of the "third" society: it is "Monte Carlo", "Alfa Romeo", "Cayman Island" and "Kalashnikov".

A possible positioning of the current Left among these three large virtual groups designates however the orientation of the empirical realization. This positioning might explain today also a lot of the real politics. For, the established Left belongs after 2000 to the class of the "manipulators" (i.e. the elite, the third society). The established Left builds without any doubt a strong and independent group of the "society of the good will" (the first society). And, the "second society" remains of course (for instance the "majority"), that was traditionally considered as "left target group", the losers of today. 
We take for absolutely actual the existence of these three global societies, even if we do not deal with the sociological description for instance on a meso-level.

The first society would be the society of the good will, already several times discussed, for which very positive interpretation is once and for all characteristic and for which the value-oriented life of this year can no longer become an open problem.

We define the second society provisionally as the one, which is fundamentally not constituted by the above described good will, without any regard to other definitions. In the following, we will try to identify it in this abstract description as the society of the "majority".

We see the third society in that virtual apparatus, that political class or elite, that global conglomeration, which power has been built in the year 1989 and thus became the concretization of that establishment, with which the "first" society identified itself so totally. This "third" society might surely be defined on the basis of a detailed analysis also as "new class".

\section{Conclusions}

The three societies are making up a configuration, which surely does not fully constitute the sociological or political reality of the global period after 1989, which is however becoming apparent behind the relevant real events.

The "third" society is the object of the self-identification of the "first", the "first" is the product of the year 1989. The "second" society lived after 1989 rather long in the shade, its emancipation began only after the first shakes of the new world order (under "shakes", we understand mainly that process, in which the self-image and the expectations of the achievements of 1989 had to see themselves confronted to the reality).

We think beforehand, that the "first" society, the one of the good will, of the culture of the criticism and of the individuality was representing in the long term, with the help of the "third" society, but also spontaneously, the product of the world historical turn, the whole society. It is therefore a big question of the history and also of the civilization, of what was and, fundamentally, what does the historical fate of the "second" society become, which is on the way to demonstrate the "majority", while the "third" society is doing everything to make an example out of the constantly changing groups of the "first" society.

The relations of the three societies are produced in the milieu, which is defined by the reality of the indebted state. It can also not hardly be different, because the indebted state is mainly the most profound definition of the globalization.

If we enquire at this point again about the reasons, why this manipulation is so successful, why a culture of the criticism is existing without empiricism, we must so have again recourse to the downfall of the Marxism [8]. The Marxism does also not play in this context any primary political or ideological role. The today situation shows, that the Marxism, independently from its acceptance, had a kind of ontological meaning, also among those, who did not share it.

They provide a new possibility of description of the global reality, in a certain analogy to the natural descriptions of our days, we look to the fact that the one description does not make superficial or deny the others, and every description refers to its truth content from the definitions of its perspectivistic peculiarity. It seems, nevertheless, that this ether of the three new "classes", as we repeat it, is already on the way to play a perceptible empirical role in the reconstruction of the current world society.

Without difficulty one can see how the deepest debates, or directly the deepest struggles of our years are concentrated around the basic elements of this virtual and abstract class formation.

One can identify how the class of the "manipulators" (roughly named: the elite) uses its most important forces for the fact that the pure existence of this class (i.e. its own existence !) cannot be factually proven. 
One can as clearly identify, that another global struggle is led to present the "class of the good will" as the "real" majority (instead of the real majority) in front of the public, which opposes only marginal groups that largely do not recognize the fundamental bases of the year 1989 .

A possible positioning of the current Left among these three large virtual groups designates however the orientation of the empirical realization. This positioning might explain today also a lot of the real politics. For, on the one hand, the established Left belongs after 2000 to the class of the "manipulators" (i.e. the elite). On the other hand, the established Left builds without any doubt a strong and independent group of the "society of the good will". And thirdly, the "third class" remains of course (for instance the "majority"), that was traditionally considered as "leftist target group".

This tripartition of the real existing Left might also explain, why its political articulation is so fragmented. A Leftist should have today three souls: one of the winners (the elite, as a member of our third class), one of the losers (as a member of our second class) and one of the man of good will (as a member of our first class), who very enjoyed in its total identification with the own system) [1].

If we were to consider the phenomenon Trump or the alternatives of the current moderated and/or extreme rights in front of the horizon of this new virtual structure, this confrontation would then yield numerous insights.

\section{References}

[1] Kiss, E. 1997. "Das Globale ist das Unmittelbarwerden des Absoluten?" In Hegel-Jahrbuch, 1996. Berlin: Akademie Verlag, pp. 33-41. (in German)

[2] Kiss, E. 2002. Monetarista globalizáció és magyar rendszerváltás. Társadalomfilozófiai tanulmányok. Budapest: Ferenczy. (in Hungarian)

[3] Ehrke, M. 2004. "Das neue Europa. Ökonomie, Politik und Gesellschaft im postkommunistischen Kapitalismus." Budapest: FES. http://library.fes.de/pdf-files/id/01456.pdf. (in German)

[4] Fukuyama, F. 1992. The End of History and the Last Man.
New York: Free Press.

[5] Kaempfer, W., Neidhöfer, H., and Ternes, B., eds. 2005. Die unsichtbare Macht. Neue Studien zu Liberalismus-Kapitalismus. Berlin: Geesthacht. (in German)

[6] Hardt, M., and Negri, A. 2000. Empire. Cambridge, Mass. London: Harvard University Press.

[7] Kiss, E. 2001. "Identitaet und Differenz-Funktionen der Logik, Logik der Funktionen. Über den Anderen, das Anderssein und die Interkulturalitaet." In Verstehen und Verstaendigung. Ethnologie, Xenologie, Interkultrurelle Philosophie, edited by Wolfdietrich Schmied-Kowarzik. Würzburg: Königshausen und Neumann, pp. 359-69. (in German)

[8] Baudrillard, J. 1986. Die göttliche Linke. München: Matthes \& Seitz. (in German)

\section{Other sources}

[9] Bernard, Fr. de. 2002. La Pauvreté durable. Paris: Félin. (in French)

[10] Csányi V. 1988. Evolúciós rendszerek. Az evolució általános elmélete. Budapest:Gondolat. (in Hungarian)

[11] Dahrendorf, R. 1984. Der Liberalismus und Europa. München, Zürich: Piper. (in German)

[12] Elias, N. 1976. Über den Prozess der Zivilisation. Soziogenetische und psychogenetische Untersuchungen. Frankfurt am Main: Suhrkamp. (in German)

[13] Erikson, E. H. 1970. Jugend und Krise. Die Psychodynamik im sozialen Wandel. Stuttgart: Klett. (in German)

[14] Gehlen, A. 1961. "Über kulturelle Kristallisation.” In Studien zur Anthropologie. Neuwied: Luchterhand. (in German)

[15] Kiss, E 2002. "Entre le néo-positivisme-néo-liberalisme et le postmoderne." In TRANS. Internet-Zeitschrift für Kulturwissenschaften. Nr. 14/2002. http://www. inst.at $/$ trans $/ 14 \mathrm{Nr} / \mathrm{kiss} 14 . \mathrm{htm}$. (in French)

[16] Kiss, E 2002. Fin de l'histoire. dans: Dictionnaire critique de la mondialisation. Paris: Lavoisier, pp. 181-3. (in French)

[17] Kiss, E. 1999. "Monetarismus und Liberalismus. Zu einer Theorie der globalen und geschichtsphilosophischen Aktualitaet." In Die Kultur des Friedens. Weltordnungsstrukturen und Friedensgestaltung, edited by Eds: Volker Bialas, Hans-Jürgen Haessler and Ernst Woit. Würzburg: Königshausen und Neumann, pp. 211-26. (in German)

[18] Kiss, E. 2000. "Menschenrechte und Menschen im Strome der Globalisierung." In Völkerrecht und Rechtsbewusstsein für eine globale Friedensordnung, edited by Ernst Woit and Joachim Klopfer. Dresden: DSS Arbeitspapiere, pp. 55-64. (in German)

[19] Kiss, E., ed. 2003. Globalizáció és/vagy posztmodern. 
Tanulmányok a jelen elméletéröl. Budapest-Székesfehérvár: Kodolányi. (in Hungarian)

[20] Kiss, E., ed. 2005. Postmoderne und/oder Rationalität. Székesfehérvár: Kodolányi. (in German)

[21] Kojeve, A. 1947. Introduction a la lecture de Hegel. Lecons sur la Philosophie de l'Esprit. Paris: Gallimard. (in French)

[22] Koselleck, R. 1984. Vergangene Zukunft. Zur Semantik geschichtlicher Zeiten. Frankfurt am Main: Suhrkamp. (in German)

[23] Krohn, W., Küppers, G., eds. 1992. Emergenz: die Entstehung von Ordnung, Organisation und Bedeutung. Frankfurt am Main: Suhrkamp. (in German)

[24] Lefebvre, H. 1972. Das Alltagsleben in der modernen Welt. Frankfurt am Main: Suhrkamp. (in German)

[25] Luhmann, N. 1973. Zweckbegriff und Systemrationalitaet Über die Funktion von Zwecken in sozialen Systemen. Frankfurt am Main: Suhrkamp. (in German)

[26] Lukács, G. 1976. A társadalmi lét ontológiájáról. Budapest:Magvető. (in Hungarian)
[27] Mazur, I., Chumakov, A. N., eds. 2003. "Globalizatsiya na mikro-, mezo- i makrourovnyakh." In Globalistika: Entsiklopedia. Moscow: Raduga. (in Russian)

[28] Meier, H., ed. 1990. Zur Diagnose der Moderne. München-Zürich: Piper Verlag. Zur Diagnose der Moderne. (in German)

[29] Michels, R. 1987. Masse, Führer, Intellektuelle. Frankfurt am Main, New York:Campus. (in German)

[30] N. N., ed. 1998. Democracy. A Foreign Affairs Reader.

[31] Rainer Piepmeier, R. 1979. "Das Ende der Geschichte." In Normen und Geschichte, edited by W. Oelmüller. Paderborn: Schöningh. Das Ende der Geschichte. (in German)

[32] Schmied-Kowarzik, W., ed. 2002. Verstehen und Verstaendigung. Ethnologie, Xenologie, Interkulturelle Philosophie. Würzburg: Könisgshausen-Neumann. (in German)

[33] Tönnies, F. 1972. Gemeinschaft und Gesellschaft. Darmstadt: Wissenschaftliche Buchgesellschaft. (in German) 